Studia Judaica 20 (2017), nr 2 (40), s. 237-263

doi:10.4467/24500100STJ.17.011.8246

Magda Sara Szwabowicz

\title{
Wydawcy w służbie idei. O pionierach hebrajskiego świeckiego ruchu wydawniczego*
}

\author{
PUBLISHERS IN THE SERVICE OF HEBREW LITERATURE: \\ THE PIONEERS OF SECULAR HEBREW PUBLISHINC
}

\begin{abstract}
The article focuses on the main secular Hebrew publishers and their role in the development of modern Hebrew literature. On the presumption that a publishing house is an institution which forms readership and drives literary production, the author shows that Hebrew publishers were not only modelling the book market but also served as essential promoters of Hebrew writings and as both financial and spiritual supporters of writers. The aim of the paper is to present the most distinguished Hebrew publishers (e.g. Ben-Avigdor or Avraham Stybel) along with their publishing initiatives which were carried out on the Polish lands from the last decade of the nineteenth century until the outbreak of the Second World War. The key issues discussed in the article are the goals publishers set for themselves, their publishing policy and, above all, their contribution to the development of different genres of Hebrew literature.
\end{abstract}

Keywords: publishing company, Hebrew literature, Ben-Avigdor, Tushiya, Avraham Yosef Stybel, Shlomo Sreberk.

Słowa kluczowe: wydawnictwo, literatura hebrajska, Ben-Awigdor, Tuszija, Awraham Josef Sztybel, Szlomo Sreberk.

* Projekt został sfinansowany ze środków Narodowego Centrum Nauki przyznanych na podstawie decyzji numer DEC-2012/07/N/HS2/02799. 
Rolą wydawnictwa jest nie tylko modelowanie i animacja rynku książkowego czy dystrybucja publikowanej literatury. Wydawnictwo jako instytucja literacka kształtuje grono czytelników i generuje produkcję literacką. Wydawca może pełnić funkcję opiekuna, mecenasa czy skromnego wielbiciela literatury, którego celem jest wspieranie jej rozwoju i twórców. Niemniej może też upatrywać w swej pracy zysku, traktując ją jako intratny interes. U zarania świeckiego hebrajskiego ruchu wydawniczego praca wydawcy prawie zawsze wiązała się z poczuciem misji. Celem było wspieranie artystów tworzących w odnowionym języku, nierzadko łączące się z przyjęciem narracji ideologicznej i chęcią realizacji założeń ruchu odrodzenia narodowego poprzez promocję literatury. O ile współcześnie częstym zamierzeniem wydawcy jest wpływanie na czytelnika i kształtowanie jego literackiego smaku, o tyle w przypadku początków hebrajskiego ruchu wydawniczego trzeba było świeckiego czytelnika stworzyć.

Pionierzy hebrajskiego ruchu wydawniczego - Ben-Awigdor (właśc. Awraham Lejb Szalkowicz) czy Awraham Josef Sztybel - poszerzyli dotychczasowe znaczenie słowa „wydawca” i nadali mu należny szacunek. Kiedy w 1916 r. w Warszawie wydano jubileuszową książeczkę upamiętniającą dwudziestopięciolecie działalności pisarskiej i wydawniczej Ben-Awigdora, jeden z autorów, Azri'el N. Frenk, opatrzył swój tekst pytaniem: „Co takiego uczynił Ben-Awigdor dla literatury hebrajskiej?”1. Na to niewinne na pozór pytanie dostajemy pełną estymy odpowiedź. Frenk, a później także inni pisarze i literaturoznawcy ${ }^{2}$, nazywa Ben-Awigdora budowniczym, wręcz „stwórcą literatury hebrajskiej”3. Termin ten będzie odpowiedni także dla innych pionierskich wydawców. Niniejszy artykuł stanowi próbę odpowiedzi na pytanie, jakie zasługi dla rozwoju literatury hebrajskiej i hebrajskiego czytelnictwa mają pionierzy hebrajskiego ruchu wydawniczego: Ben-Awigdor, Szlomo Sreberk i Awraham Josef Sztybel. Najważniejszymi zagadnieniami będą cele, jakie wyznaczyli sobie wydawcy, obrana przez nich polityka wydawnicza oraz efekty ich pracy, czyli wkład w rozwój różnych gatunków literatury hebrajskiej.

Azri'el Natan Frenk, Ben-Awigdor la-sifrut ha-iwrit ma paal?, [w:] Ben-Awigdor la-chag jowlo, Warsza 1916, s. 14-15.

${ }^{2}$ Por. Eli'ezer Rafael Malachi, Ben-Awigdor, [w:] tenże, Masot we-reszimot, Niu Jork 1937, s. 150, 156; Meir Ja'akow Freid, Sz. L. Gordon, Ben-Awigdor, „Sifrej Agora”, „Tuszija”, „Central”, [w:] Jamim we-szanim, t. 2, thum. Awraham Zamir, Tel Awiw 1939, s. 157; Josef Chaim Brenner, Ben-Awigdor, [w:] tenże, Ketawim, t. 4, Tel Awiw 1985, s. 1446.

${ }^{3}$ Frenk, Ben-Awigdor..., s. 17, 19. 


\section{Początki hebrajskiego świeckiego ruchu wydawniczego}

Jeszcze na początku XIX w. hebrajski świecki ruch wydawniczy był w powijakach. Autorzy osobiście musieli się starać o publikację swych dzieł, a także o zdobycie niezbędnych na ten cel funduszy. Ze względu na koszty wydania książek przyjętym zwyczajem była zbiórka datków wśród znajomych pisarza na publikację dedykowanej mu na specjalną okazję księgi jubileuszowej ${ }^{4}$. Co więcej, nierzadko również dystrybucja książek leżała w gestii autora.

Zanim na szerszą skalę zaczęto otwierać księgarnie, dystrybucją książek zajmowali się wędrowni sprzedawcy, najczęściej zdobywający je bezpośrednio od drukarzy. Częstym zwyczajem była „prenumerata” książek jeszcze przed ich publikacją, a nierzadko - przed ich napisaniem, co miało gwarantować pokrycie kosztów wydania i sprzedaży druków ${ }^{5}$. W konsekwencji tej przyjętej wówczas praktyki pisarze często osobiście zabiegali o prenumeratę swych dzieł, nierzadko wędrując od domu do domu niczym domokrążcy .

Stopniowa modernizacja kultury żydowskiej, zarzucanie tradycyjnego modelu życia na rzecz kultury świeckiej czy zmiany w wychowaniu dzieci wiązały się ze wzrostem zainteresowania i zapotrzebowania na świecką literaturę żydowską i hebrajską. Sekularyzacja społeczeństwa z jednej strony oraz postępująca poczytność popularnej literatury jidysz z drugiej generowały nowy model żydowskiego czytelnika. Kręgi czytelnicze poszerzyły się także o kobiety i dzieci, co prowadziło do szybkich przeobrażeń rynku książkowego. Liczba księgarni w Imperium Rosyjskim raptownie

${ }^{4}$ Jochanan Pograbinski, Le-toldot ha-molut ha-iwrit, „Ha-Sefer Ha-Iwri” 9 (1950/51), s. 37.

${ }^{5}$ Chagit Cohen, Be-chanuto szel mocher ha-sefarim, Jeruszalajim 2006, s. 23.

${ }^{6}$ Szalom Ja'akow Abramowicz (jid. Szolem Jankew Abramowicz), jeden z ojców współczesnej literatury żydowskiej (także hebrajskiej), nie bez przyczyny nie tylko na stałe utrwalił w swych dziełach postać wędrownego sprzedawcy książek, ale i obrał sobie przydomek „mocher sefarim” (dosł. „sprzedawca książek”). O statusie pisarzy, nieraz przypominających żebraków, zob. Szalom Ja'akow Abramowicz, Ejn miszpat, Żytomir 1887, s. 48-52. Avner Holtzman w swoim artykule opisuje trudy i przykrości towarzyszące publikacji powieści Aleksandra Zyskinda Rabinowicza (Aleksander Zyskind Rabinowicz, Al ha-perek, Warsza 1887). W rzeczywistości wydanie książki (za pośrednictwem właściciela warszawskiej księgarni, Abrahama Cukermana) nie tylko nie przyniosło Rabinowiczowi oczekiwanego sukcesu materialnego, lecz przeciwnie - autor zmuszony był osobiście zadbać o dystrybucję książek, własnoręcznie je roznosząc od domu do domu. Publikacja twórczości - marzenie każdego pisarza - była więc okupiona upokorzeniem i nadwątlonym poczuciem godności autora. Avner Holtzman, „Szalem aszalem lahem be-ad jecirej rucham be-kesef male”: al huldata szel ha-sifrut ha-iwrit ke-ma'arechet kalkalit, „Ot” 3 (2013), s. 21-23; wersja online: http://humanities1.tau.ac.il/kipp/images/OT3_Holzman.pdf [dostęp: 15 grudnia 2016]. 
wzrosła. Podczas gdy na początku lat sześćdziesiątych XIX w. można było je liczyć tylko w dziesiątkach, w trzy dekady później ich liczba sięgnęła tysięcy ${ }^{7}$. Oprócz sprzedaży co większe sklepy pełniły jednocześnie funkcję wydawnictwa bądź wypożyczalni książek oraz stanowiły miejsce spotkań towarzyskich. Z czasem dystrybucją książek zajęły się redakcje gazet, oferując książki w atrakcyjnej cenie w zamian za prenumeratę czasopisma. Nadal brakowało jednak zorganizowanego ruchu wydawniczego oraz dystrybucyjnego.

Tę sytuację postanowili zmienić członkowie elitarnego ugrupowania „Benej Mosze” (Synowie Mojżesza) ${ }^{8}$, którzy dążyli do poprawy żydowskiej edukacji w diasporze ${ }^{9}$. Krytykując niewystarczającą dbałość „Miłośników Syjonu" o edukację mas w duchu narodowym, zaczęli wydawać tematyczne książeczki poświęcone sprawom żydowskim oraz periodyk „Michtawim me-Erec-Israel" [Listy z Ziemi Izraela]. Kolejnym krokiem było powołanie pierwszej hebrajskiej świeckiej oficyny wydawniczej. Jednak powstanie „Achi'asaf” poprzedził inny pionierski projekt wydawniczy jednego człowieka.

Kiedy oddział centralny „Benej Mosze” przeniósł się do Warszawy (1890), prace sekretarza zaproponowano Awrahamowi Lejbowi Szalkowiczowi ${ }^{10}$. Nie sposób było wtedy przypuszczać, że przyjazd młodego, dwudziestoczteroletniego wówczas Szalkowicza z Wilna na zawsze zmieni oblicze żydowskiego, a w szczególności hebrajskiego ruchu wydawniczego. Szalkowicz przybył do Warszawy w 1891 r. i w ramach swej pracy miał

7 W 1864 r. w Imperium Rosyjskim istniały 63 księgarnie, natomiast w latach 18931894 ich liczba sięgała trzech tysięcy. Cohen, Be-chanuto..., s. 24.

8 Tajne ugrupowanie, które założył Achad Ha-Am (Aszer Cwi Ginzberg) w Odessie w 1889 r. Wśród jego członków znaleźli się intelektualiści i działacze społeczni związani z ruchem „Miłośników Syjonu”. Głównym celem „Benej Mosze” była popularyzacja wartości narodowych poprzez edukację i kulturę. Pierwsza centrala organizacji znajdowała się w Odessie, kolejna w Warszawie (1890-1893), następna w Jafie. W 1894 r. zdecydowano o powołaniu dwóch centrów - ośrodka wschodnioeuropejskiego w Wilnie i zachodnioeuropejskiego w Berlinie. Organizacja działała przez osiem lat. Ester Sztajn-Aszkenazi, Agudat „Benej Mosze”, merkaza be-Warsza, zikata le-tnuat Chibat Cijon, „Ha-Cijonut” 11 (1986), s. 29-31, http://humanities1.tau.ac.il/zionism/templates/ol_similu/images/zionism_journals/ zionism_11/4.pdf [dostęp: 13 kwietnia 2016].

${ }^{9}$ Dúżą wage przywiązywali do edukacji dziewcząt, a także zbierali książki w celu powołania bibliotek w Palestynie.

${ }^{10}$ Awraham Lejb Szalkowicz (1866-1921) urodził w niewielkim mieście Żołudek w ówczesnej guberni wileńskiej, dorastał w Zdzięciole k. Grodna. Pobierał nauki w litewskich jesziwach. W celu poszerzenia swej świeckiej edukacji przeniósł się do Kowna, gdzie zaangażował się w działalność ruchu „Miłośników Syjonu”. Po przeprowadzce do Wilna w 1889 r. zaczął publikować pierwsze artykuły w „Ha-Melic”. 
się także zająć przygotowaniem do druku świątecznej publikacji. Tomik Sipurej ha-Szaron, wydany na Pesach, miał dać początek biblioteczce dla młodzieży, jednak nie odniósł dużego sukcesu ${ }^{11}$. Szalkowicz, znany pod pseudonimem Ben-Awigdor, skoncentrował swe siły na urzeczywistnieniu marzenia, z którym nosił się od przyjazdu do Warszawy: „wydania serii małych i tanich książek w dziedzinie literatury pięknej”"12.

\section{Wydawniczy przewrót}

Jak pisała Szulamit Szelhaw, Ben-Awigdor dokonał dzieła niemożliwego ${ }^{13}$. Nie minęło pół roku od jego przyjazdu do Warszawy, kiedy wydał Sifrej agora [Książki za grosz]. Ben-Awigdor był nie tylko autorem i redaktorem pierwszych publikacji, ale zajmował się także korektą, korespondencją ze sprzedawcami, umieszczaniem w prasie ogłoszeń o publikacjach oraz sprzedażą i dystrybucją, łącznie z pakowaniem i wysyłką książek ${ }^{14}$. Jak zapowiedziano, kolejne pozycje w serii ukazywały się z dwutygodniową częstotliwością. W pierwszych latach publikowania Sifrej agora wydano blisko pięćdziesiąt książeczek.

Seria wywołała przełom w świecie literatury hebrajskiej. Nowatorskie podejście Ben-Awigdora polegało nie tylko na publikacji dzieł mniej znanych pisarzy, ale również na formie, w jakiej książki były wydawane. Celem Ben-Awigdora, po części zainspirowanego rosnącą ówcześnie popularnością literatury jidysz, było dotarcie do mas - zarówno więc treści, jak i cenę publikacji starał się dostosować do gustów i możliwości finansowych czytelników ${ }^{15}$. Zmienił się status książki hebrajskiej zarezerwowanej dotychczas dla intelektualnych elit. Pozycje Sifrej agora miały trafiać nie tylko do uczonych, ale do każdego, kto władał hebrajskim i chciał w nim czytać.

${ }^{11}$ Ukazał się tylko jeden zeszyt. Jak odnotowuje jednak Ofek, Sipurej ha-Szaron zwiastowały zmiany w literaturze hebrajskiej dla dzieci, wprowadzając do niej narrację syjonistyczną i idee odrodzenia narodowego. Uriel Ofek, Sifrut ha-jeladim ha-iwrit - ha-hatchala, Tel Awiw 1979, s. 226-227.

12 Z listu do Jehoasza (Jehoszua-Szlomo Blumgarten, 1872-1927, poeta tworzący w jidysz). Cyt. za: Szulamit Szelhaw, Ben-Awigdor we-sifrej agora, ha-mahalach ha-moli we-ha-mischari, „Sadan” 4 (2000), s. 286.

13 Tamże, s. 293.

14 Tamże, s. 291, 293.

${ }_{15}$ Na podstawie analizy katalogów książkowych wydanych w Rosji i Galicji w II połowie XIX w. Cohen zaobserwowała spadek cen literatury religijnej (hebrajskiej) oraz jidysz. Inaczej było w przypadku świeckiej literatury hebrajskiej czy obcej, których ceny spadły tylko minimalnie. Cohen, Be-chanuto..., s. 128-138. 
Przeznaczenie i funkcja książki hebrajskiej zostały poszerzone - oprócz krzewienia nauki i idei odrodzenia narodowego jej równie ważnym zadaniem było dostarczenie czytelnikom przyjemności lektury. Ben-Awigdor symbolicznie przesunął uwagę czytelnika z tematów narodowych - jedynych właściwych według ideologii Achad Ha-Ama ${ }^{16}$ - na życie codzienne Żydów. Pierwsza pozycja z serii „,grosikowej”: „Lea handlarka ryb”, nosiła podtytuł „Z ulicy żydowskiej” i była realistycznym odzwierciedleniem codziennego życia żydowskiej straganiarki. Ben-Awigdor ukazywał, że język hebrajski nie jest zarezerwowany dla filozoficznych dysput syjonistów, intelektualistów i pisarzy, ale może być także językiem przeciętnego Żyda ${ }^{17}$.

Część inteligencji żydowskiej nie była jednak gotowa zaakceptować nowoczesnej postawy Awrahama L. Szalkowicza - pisarza i wydawcy. Święte oburzenie, jakie wywołało użycie hebrajskiego przez prostych Żydów, uwiecznione w opowiadaniu „Lea handlarka ryb”, żywo odtworzył Azri’el N. Frenk. „Biada nam, ten człowiek przybliża klęskę naszego języka”, dawały się słyszeć głosy Żydów gromadzących się w warszawskiej księgarni Eli'ezera Icchaka Szapiry, ówczesnego „klubu maskili”"18. Mimo dezaprobaty części pisarzy haskalowych starszego pokolenia dla

${ }^{16}$ Wokół poglądów Achad Ha-Ama rozpętała się sławna, jedna z ważniejszych w dziejach nowożytnej literatury hebrajskiej polemika nad rolą literatury hebrajskiej. Była ona ściśle związana z artykułem programowym periodyku „Ha-Sziloach”, w którym Achad Ha-Am wyłożył swoje poglądy (Teudat Ha-Sziloach). Według manifestu Achad Ha-Ama w czasopiśmie miały ukazywać się teksty, łącznie z twórczością literacką, dotyczące najważniejszych problemów narodu żydowskiego. Achad Ha-Am twierdził, że ówczesna literatura hebrajska nie była w stanie dostarczyć czytelnikowi przyjemności estetycznej, toteż pisarze powinni skupić się przede wszystkim na rozwijaniu świadomości narodowej Żydów. Swoją myśl rozwinął w kolejnym artykule - Corech wi-jecholet. Głównym adwersarzem Achad Ha-Ama był pisarz Micha Josef Berdyczewski, a za nim także Jehoszua Ozjasz Thon i Mordechaj Ehrenpreis. Por. Achad Ha-Am, Teudat Ha-Sziloach, „Ha-Sziloach” 1 (1896), s. 1-6; tenże, Corech wi-jecholet, „Ha-Sziloach” 3 (1896), s. 268-274. Na temat polemiki Achad Ha-Ama z grupą „Młodych pisarzy" (Micha J. Berdyczewski, Jehoszua O. Thon, Mordechaj Ehrenpreis) zob. Ali Mohamed Abd El-Rahman Attia, The Controversy between Ahad Ha-Am and the Young Writers, [w:] tenże, The Hebrew Periodical „Ha-Shiloah” (1896-1919), Jerusalem 1991, s. 55-64; Avner Holtzman, Micha Josef Berdiczewski, Jeruszalajim 2011, s. 103-131; Shoshana Ronen, "Tse'irim”: The Dispute in „Ha-Shiloah”, [w:] taż, A Prophet of Consolation on the Threshold of Destruction: Yehoshua Ozjasz Thon, an Intellectual Portrait, Warsaw 2015, s. 61-68.

${ }_{17}$ Ze'ev Gries pisał nawet, że dzięki Ben-Awigdorowi hebrajski stał się językiem dnia powszedniego, językiem świeckim dającym Żydom dostęp do nowoczesnego świata. Ze'ev Gries, The Revolution in the World of Hebrew Books at the Start of the Twentieth Century, [w:] tenże, The Book in the Jewish World, 1700-1900, Oxford 2007, s. 185.

${ }^{18}$ Oburzenie zebranych wywołały nieznane im dotychczas z Biblii czy Miszny wyrażenia w języku hebrajskim. Frenk, Ben-Awigdor..., s. 14-15. O księgarni Szapiry zob. Cohen, Be-chanuto..., s. 38-44. 
działalności pisarskiej Szalkowicza i jego taniej biblioteczki ${ }^{19}$ wielu wybitnych twórców zdecydowało się na publikację swych dzieł w domu wydawniczym Ben-Awigdora (m.in. Icchak Lejb Perec, Dawid Friszman, Reuwen Brajnin czy Szmuel Lejb Gordon $)^{20}$.

Masowa produkcja serii tanich książeczek kieszonkowych umożliwiła kolejną zmianę - zakup książki stał się wydatkiem, na który przeciętny Żyd mógł sobie pozwolić. Gwarancją sukcesu Sifrej agora była taktyka rynkowa, jaką przyjął Ben-Awigdor. Wydawca proponował dogodne warunki prenumeraty książek, zapewniając sobie w ten sposób stałe grono odbiorców. Jak pisał Eli'ezer R. Malachi, to dzięki Ben-Awigdorowi książka hebrajska przedarła się na ulicę żydowską, a za pomocą Sifrej agora i kolejnych przedsięwzięć edytorskich, jak wydawnictwo „Tuszija”, Ben-Awigdor stworzył czytelnika, który jednocześnie był nabywcą książek ${ }^{21}$. O sukcesie serii „grosikowej” świadczyły późniejsze reedycje biblioteczki (w roku 1912 oraz 1921).

Ben-Awigdor prezentował inny od przyjętego ówcześnie stosunek do pracy wydawcy oraz pracy pisarza jako wytwórcy literatury. Rola wydawcy postrzegana była dotychczas jako dodatkowe, zazwyczaj filantropijne zajęcie. Ben-Awigdor zaś traktował pracę wydawcy, podobnie jak pracę literacką, jako profesję, pełnowymiarowe zajęcie, za które wykonawcy należy się wynagrodzenie. W manifeście załączonym do pierwszej książki w serii Sifrej agora informował o wypłacie honorarium dla autorów publikujących w jego serii ${ }^{22}$. Była to nowość, do tej pory bowiem

19 Jak ujął w swych wspomnieniach Ben-Awigdor, Aleksander Cederbaum (1816-1893), wydawca jednego z ważniejszych pism hebrajskich w Imperium Rosyjskim - „Ha-Melic” (1860-1904) - ogłosił bojkot Sifrej agora, nie zgadzając się na publikację artykułów, które miałyby jakkolwiek promować serię wydawniczą Szalkowicza. Jednak wskutek polemiki rozgorzałej wokół drugiego tomu z tej serii - a uczestniczyli w niej tak prominentni pisarze, jak Mosze Liljenblum i Achad Ha-Am - stosunek Cederbauma do Szalkowicza złagodniał. Po roku od rozpoczęcia wydawania biblioteczki Cederbaum udzielił zgody na drukowanie reklam, a także pozytywnych recenzji Sifrej agora. Więcej na ten temat zob. Szelhaw, Ben-Awigdor..., s. 293-299.

${ }^{20}$ Spis wszystkich publikacji wydanych w ramach serii Sifrej agora zob. Ester Lapon-Kandelshein, „Sifrej agora”: sifrut jafa mekorit we-modernit be-iwrit be-mizrach Ejropa (1891-1896), „Gal-Ed” 24 (2015), s. 115-144.

${ }^{21}$ Malachi, Ben-Awigdor..., s. 156.

${ }_{22}$ Manifest El chowewej sefat ewer we-sifruta! [Do wielbicieli języka i literatury hebrajskiej] był w rzeczywistości manifestem literackim, który postrzegany jest dziś jako artykuł programowy prądu literackiego „Ha-Mahalach He-Chadasz” [Nowy Ruch], który wyłonił się ze sprzeciwu wobec literatury haskali. Pisarze, których twórczość wpisywała się w założenia „Nowego Ruchu” (m.in. Reuwen Brajnin, Ezra Goldin, Izrael Chaim Tawiów) postulowali redefinicję literatury hebrajskiej zarówno w aspekcie jej tematyki i prezentowanych wartości, jak i pod względem stylistycznym. Sprzeciwiali się górnolotności literatury haskalowej i języka, w jakim była pisana (styl melicy). Domagali się literatury będącej odzwier- 
[pisarze] utrzymywali się z tego, z czego mogli wyżyć: jeden z handlu, inny z uczenia, a jeszcze inny ze swatów [...], a kiedy kończyli pracę chwytali za pióro i pisali. Kiedy [pisarz] potrzebował pieniędzy, bo jego biznes upadł bądź miał córkę na wydaniu, brał do torby swoje książki i chodził po domach darczyńców, zbierając datki²3.

Honorarium w postaci pieniężnej było nowością, wedle przyjętej metody bowiem wydawca honorował pisarza poprzez ofiarowanie mu egzemplarzy jego publikacji ${ }^{24}$. Rezultatem obranej przez Ben-Awigdora polityki było nie tylko przekształcenie pracy pisarza i wydawcy w pracę zarobkową, ale symboliczne nadanie ich profesji godności.

\section{Ben-Awigdor - wydawca jako Stwórca}

Ben-Awigdor, dziś postrzegany jako ojciec świeckiego ruchu wydawniczego, wyznaczył sobie niebagatelną misję bycia stwórcą nie tylko literatury hebrajskiej, ale i jej czytelnika. Wieczny optymista, jak określił go współpracujący z nim przez pewien czas poeta Ja’akow Fichman, charakteryzował się ułańską fantazją. Misja ta przecież nie tylko wymagała inwestycji finansowej, ale pewności siebie i gotowości do poniesienia kosztów oraz nakładów pracy.

Seria Sifrej agora była tylko preludium do realizacji wyznaczonych sobie przez wydawcę celów. Już jednak w tym pierwszym projekcie zarysowywała się polityka wydawnicza Ben-Awigdora, którą wraz z założeniem „Tusziji” szczegółowo wyartykułował. Publikacje Sifrej agora zaczęły się ukazywać w 1891 r., kiedy Ben-Awigdor pełnił funkcję sekretarza warszawskiego oddziału „Benej Mosze”. Z końcem 1892 r. członkowie organizacji powołali do życia wydawnictwo „Achi'asaf” - Ben-Awigdor był nie tylko jednym z inicjatorów przedsięwzięcia, lecz nieoficjalnie kierował nim przez pierwsze trzy lata jego istnienia ${ }^{25}$.

ciedleniem rzeczywistości, zaangażowanej społecznie, pisanej językiem „naturalnym”, a nie stylizowanym. Gilboa stwierdza, że w rzeczywistości „Ha-Mahalach He-Chadasz” był odpowiednikiem europejskiego naturalizmu. Zob. Menucha Gilboa, Ha-Mahalach He-Chadasz we-michuca lo, Tel Awiw 1991. Manifest Ben-Awigdora załączony jest w formie aneksu do książki - por. Ben-Awigdor, El chowewej sefat ewer we-sifruta!, [w:] tamże, s. 83-86. Praktyczne aspekty manifestu Ben-Awigdora (dostosowanie cen książek do możliwości finansowych przeciętnego czytelnika, wypłacanie honorarium pisarzom, stworzenie pełnego systemu literackiego) zob. Holtzman, „Szalem aszalem lahem be-ad jecirej rucham be-kesef male"..., s. 27-28.

${ }^{23}$ Frenk, Ben-Awigdor..., s. 13. Wszystkie przekłady zostały dokonane przez autorkę artykułu.

${ }^{24}$ Tamże, s. 15.

${ }^{25}$ Założenie wydawnictwa wsparli finansowo Eli'ezer Kaplan, Matithaju Cohen i Ze'ew Gluskin - członkowie „Benej Mosze”. 
Nowa oficyna pozostawała jednak pod silnym wpływem Achad Ha-Ama, z jej polityką wydawniczą wiązała się więc bardzo konkretna ideologia: zadaniem „Achi'asaf” z założenia miało być wzbogacanie i kształtowanie myśli narodowej ${ }^{26}$. Między Ben-Awigdorem, postulującym literaturę dla narodu, w rozumieniu ludowym, a Achad Ha-Amem zaczęły się zarysowywać znaczące różnice poglądów. Ben-Awigdor był redaktorem pierwszych tomów „Luach Achi'asaf” (Warszawa 1893-1904, 1923), rocznika publikowanego w wydawnictwie, który miał zawierać literaturę piękną dającą przyjemność lektury oraz praktyczne informacje ze świata żydowskiego ${ }^{27}$. Pomimo tych założeń, które zresztą osobiście sformułował, Ben-Awigdor nie mógł w wydawnictwie „Achi'asaf” w pełni zrealizować swoich szeroko zakrojonych planów edytorskich ${ }^{28}$. W 1895 r. wyprzedał więc swoje udziały i odszedł z wydawnictwa. W 1896 r. ufundował oficynę wydawniczą „Tuszija” (Mądrość) $)^{29}$, swój indywidualny projekt.

Jako że Ben-Awigdor myślał i planował z rozmachem, jego marzeniem, a w rzeczywistości celem „Tusziji”, było stworzenie pełnej literatury. Prospekt wydawnictwa zapowiadał, że w „Tusziji” ukażą się: klasyka literatury światowej - „od dzieł najstarszych do najnowszych, w wysokiej klasy przekładach z oryginału”; literatura piękna - „opowiadania, szkice literackie, dramaty, poezja itd.; nowa i stara, w oryginale i przekładzie”; prace naukowe - ,przystępnie opracowane książki naukowe ze wszystkich dziedzin nauk przyrodniczych, jak: fizyka, chemia, fizjologia, botanika, zoologia, geologia, astronomia i inne”; studia z „nauk społecznych, jak: filozofia, socjologia, historia, dzieje literatury i inne" 30 .

Zarówno w dziedzinie literatury pięknej, jak i naukowej „Tuszija” miała publikować oryginalne prace twórców i badaczy hebrajskich oraz

${ }^{26}$ Malachi, Ben-Awigdor..., s. 155.

${ }^{27}$ Więcej o „Luach Achi'asaf” zob. Menucha Gilboa, Achi'asaf, [w:] taż, Leksikon ha-itonut ha-iwrit ba-meot ha-18 we-ha-19, Jeruszalajim 1992, s. 374-378; Magda Sara Szwabowicz, Yehoshua Thon's „Luah Ahi'asaf”: An Editor and a Journal, [w:] A Romantic Polish Jew: Rabbi Ozjasz Thon from Various Perspectives, red. Michał Galas, Shoshana Ronen, Kraków 2015, s. 107-117.

${ }^{28}$ To najczęściej podawana przyczyna odejścia Ben-Awigdora z „Achi'asaf”. Innym powodem mogły być nieporozumienia ze współpracownikami. Zob. Bernard Jakubowicz, Asot wa-hafec sefarim harbe. Le-tolodeja szel hoca'at ha-sefarim „Central”-,Merkaz” be-Warsza (1911-1933), nieopublikowana praca magisterska pod kierunkiem prof. Nurit Govrin, Uniwersytet w Tel Awiwie, 1997, przyp. 69, s. 93.

${ }_{29}$ Wspólnikami Ben-Awigdora byli Tuwja Hindes i Ja'akow Remberg. O zbiórce funduszy na nowe wydawnictwo i jego powstaniu zob. Frenk, Ben-Awigdor..., s. 18; Jakubowicz, Asot wa-hafec..., s. 70.

${ }^{30}$ Cyt. za: Pograbinski, Le-toldot..., s. 44-45. 
przekłady. Ważnym elementem programowym było zachowanie odpowiedniej proporcji między publikacjami żydowskimi, tj. zajmującymi się tematami dotyczącymi Żydów bądź tworzonymi przez autorów żydowskich, a literaturą światową i pracami naukowymi niezwiązanymi ze studiami żydowskimi ${ }^{31}$. Ten punkt programu wydawniczego był główną różnicą ideologiczną między „Tusziją” a „Achi'asafem”.

„Tuszija” z założenia miała wydawać książki „dla każdego”, czyli publikacje zaspokajające potrzeby i odpowiadające gustom każdej warstwy społeczeństwa żydowskiego. Tym samym wydawnictwo nie miało charakteru elitarystycznego jak „Achi'asaf”, ale ludowy. Niemniej jednak przedkładanie ilości nad jakością (publikowanych materiałów, a także formy) okazało się zgubne, spotkając się także z zasadną krytyką ${ }^{32}$. $\mathrm{Z}$ drugiej strony, jak wynika ze wspomnień i tekstów współczesnych mu pisarzy, grzech niestarannej selekcji wydawniczej wybaczano Ben-Awigdorowi, gdyż nieocenione były troska i wspaniałomyślność, jakimi wykazał się wobec debiutujących pisarzy, wspierając ich na początku kariery literackiej33.

We wspomnieniach poety Ja'akowa Fichmana, który znał Ben-Awigdora osobiście i nie skąpił mu obiektywnej krytyki, znajdziemy wyrazy wdzięczności dla legendarnego wydawcy. Niewykluczone, iż pomoc Ben-Awigdora była istotna dla rozwoju kariery literackiej młodego Fichmana. „Znałem go od czasu moich pierwszych kroków w literaturze”, pisał. „Pierwsze honorarium za moje debiutanckie wiersze, które ukazały się w »Olam Katan «, dostałem bezpośrednio od niego [...] mój pierwszy tom poezji wydał zaś w czasie, kiedy już nie wierzyłem, że ktoś je wybawi”34.

Szczytowym osiągnięciem „Tusziji” była seria wydawnicza Ha-Biblioteka Ha-Iwrit [Biblioteka Hebrajska] ${ }^{35}$. Przez zaledwie cztery lata (1898-1902)

31 Jakubowicz, Asot wa-hafec..., s. 71.

$32 \mathrm{O}$ niestarannej selekcji Ben-Awigdora w wyborze publikowanych prac por. Ja'akow Fichman, Ruchot menagnot, Jeruszalajim 1952, s. 390-392. Malachi natomiast zaznaczał techniczne niedoskonałości publikacji „Tusziji”, przede wszystkim wizualną stronę książek, które drukowane były na słabej jakości papierze i przy użyciu mało czytelnych czcionek. Malachi, Ben-Awigdor..., s. 155-156; podobnie Szulamit Szelhaw, Mi-kawanot le-ma'asim: perek riszon be-toldot ha-molut ha-iwrit ha-chilonit ha-modernit, praca magisterska pod kierunkiem prof. Nurit Govrin, Uniwersytet w Tel Awiwie, 1994, s. 177.

${ }_{33}$ Ben-Awigdor wydał pierwsze tomy opowiadań Josefa Chaima Brennera, Uriego Nisana Gnessina, Gerszona Szofmana. Zob. także Szelhaw, Mi-kawanot..., s. 163-165; Brenner, Ben-Awigdor..., s. 1446.

${ }^{34}$ Fichman, Ruchot menagnot..., s. 393.

35 Szczegółowo na temat krystalizacji planu wydawania serii oraz etapów jego realizacji wraz z recepcją Biblioteki Hebrajskiej zob. Szelhaw, Mi-kawanot..., s. 163-181. 
opublikowano w niej dwieście pozycji. Kolejne książki - ze wszystkich dziedzin literatury hebrajskiej (w myśl manifestu) - drukowano w co najmniej tysięcznym nakładzie z tygodniową częstotliwością ${ }^{36}$. Rozpowszechniane były przede wszystkim za pomocą subskrypcji i - jak wspominał Ben-Awigdor - w pół roku od rozpoczęcia druku serię prenumerowało dwa tysiące subskrybentów ${ }^{37}$. Biblioteka Hebrajska poprzez liczbę publikacji oraz szerokie ich spektrum tematyczne zapoczątkowała - jak ujął to Lewinson - nową epokę w dziejach wydawnictwa hebrajskiego. Była literalnym oknem na świat, poszerzała horyzonty hebrajskich twórców i czytelników ${ }^{38}$. Wydano w niej dzieła prominentnych współczesnych pisarzy hebrajskich, klasyków literatury światowej, a także rozprawy naukowe - w oryginale i przekładzie ${ }^{39}$.

Odbiorcą książki, którego Ben-Awigdor nie pominął, a wręcz przeciwnie - o którego pieczołowicie dbał - był młody i najmłodszy czytelnik. Ben-Awigdor wyszukiwał autorów parających się pisaniem podręczników, czytanek i adaptacji literackich czy oryginalnej twórczości dla dzieci i młodzieży, publikował ich prace i zapraszał, jak Israela Binjamina Lewnera ${ }^{40}$, Arona Luboszyckiego, Israela Chaima Tawiowa, Noacha Pinesa czy Szlomo Bermana, do stałej współpracy z wydawnictwem. To on odkrył i docenił twórczość Jehudy Sztajnberga, kiedy ten - ignorowany przez innych wydawców - był już na skraju rozpaczy ${ }^{41}$. Dzięki publikacji Ba-ir u-wa-ja'ar [W mieście i w lesie] („Tuszija”, 1896) Sztajnberg zaistniał w hebrajskim świecie literackim, a z czasem dał się poznać jako niezwykle kreatywny i płodny autor ${ }^{42}$.

W 1898 r. „Tuszija” wypuściła swoją pierwszą serię wydawniczą Biblioteka li-wnej ha-neurim [Biblioteka dla Młodzieży], która w rzeczywistości podzielona była na dwie serie: „dla dzieci” i „dla młodzieży”³.

36 Awraham Lewinson, Ha-tenua ha-iwrit ba-gola, Warsza 1935, s. 201.

37 Szelhaw, Mi-kawanot..., s. 177.

${ }^{38}$ Lewinson, Ha-tenua..., s. 201.

${ }^{39}$ Lista publikacji, które ukazały się w Bibliotece Hebrajskiej, załączona jest w pracy magisterskiej Szulamit Szelhaw. Zob. Szelhaw, Mi-kawanot..., s. 212-216.

${ }^{40}$ Lewnera mianował redaktorem dodatku dla dzieci „Ha-chaim we-ha-tewa” [Życie i Przyroda] (Wilno 1905-1906) dołączanego do wileńskiego „Ha-Zman” (1903-1915; Ben-Awigdor był jednym $\mathrm{z}$ inicjatorów pisma).

${ }^{41}$ Uriel Ofek, Szelosza sze-katwu le-jeladim, „Moznaim” 16 (1963), nr 2, s. 140.

${ }^{42}$ Do najczęściej uprawianych przez niego form literackich należały bajki, przypowiastki biblijne, opowiadania chasydzkie. Opracowywał także liczne czytanki i podręczniki hebrajskie. Publikacjami adresowanymi do najmłodszych czytelników zyskał sobie przydomek „hebrajskiego Andersena”. Tamże, s. 141.

${ }^{43}$ Ofek, Sifrut ha-jeladim..., s. 233. 
W biblioteczce dla dzieci ukazywały się przede wszystkim krótkie opowiadania, agady, piosenki i krótkie czytanki, seria młodzieżowa zaś oferowała młodemu czytelnikowi wybór tłumaczeń bądź adaptacje powieści i opowiadań młodzieżowych autorów zagranicznych ${ }^{44}$ oraz żydowskich $^{45}$. Wśród nich znalazły się dzieła klasyki literatury młodzieżowej, jak Ostatni Mohikanin czy Przypadki Robinsona Crusoe, opowiadania o bohaterach narodu żydowskiego (seria Mi-giborej ha-uma autorstwa Szlomo Bermana), a także legendy indyjskie czy kaukaskie. Przekłady i adaptacje opracowane zostały przez pionierów hebrajskiej literatury dziecięcej: Israela B. Lewnera, Arona Luboszyckiego, Jehudę Grazowskiego (później: Gur) czy Jehudę Sztajnberga ${ }^{46}$. W ciągu trzech lat w ramach serii Biblioteka dla Młodzieży ukazało się blisko trzysta książeczek.

Nie były to jedyne serie dla młodych czytelników wydane w „Tusziji”. Jak zauważał Fichman, każdy projekt czy seria wydawnicza przybierały w wyobraźni Ben-Awigdora kształt przepastnej biblioteki ${ }^{47}$. Toteż w 1907 r. zaczęto jednocześnie drukować trzy biblioteczki dopasowane do grup wiekowych: seria Nicanim [Pąki] przeznaczona była dla dzieci najmłodszych, Perachim [Kwiaty] - dla nieco starszych, a Bikurim [Pierwsze Owoce] - dla młodzieży. Podobnie jak Biblioteka dla Młodzieży zawierały literaturę obcą w tłumaczeniu lub adaptacjach bądź też oryginalną twórczość pisarzy hebrajskich. W serii Nicanim ukazało się 100 zwokalizowanych książeczek (przekłady baśni Andersena, opowiadania ludowe, bajeczki, piosenki). Na serię Perachim złożyło się 250 zeszytów, w tym aż 150 opracowanych przez Sztajnberga ${ }^{48}$. W Bikurim ukazało się 200 tytułów ${ }^{49}$, najwięcej autorstwa szwagra Ben-Awigdora - Szmuela Lejba Gordona ${ }^{50}$.

${ }^{44}$ M.in. Edmunda de Amicisa, braci Grimm, Jamesa Coopera, Marka Twaina, Lwa Tołstoja czy Wiktora Hugo.

${ }^{45}$ Meira (Markusa) Lehmanna, Jehudy Sztajnberga, Eljahu Majdanka, Chemdy Ben-Jehuda, Aleksandra Z. Rabinowicza, Israela B. Lewnera, Moszego Horlika, Pesacha Kaplana.

${ }^{46} \mathrm{O}$ trzech pionierach hebrajskiej literatury dziecięcej - Lewnerze, Grazowskim i Sztajnbergu, zob. Ofek, Szelosza sze-katwu...

${ }^{47}$ Fichman, Ruchot menagnot..., s. 392.

${ }^{48}$ Do grona autorów hebrajskich, którzy mieli swój wkład w serię, należeli m.in.: Aleksander Z. Rabinowicz, Zalman Szneor, Icchak Kacenelson, Jeszajahu Berszadski, Falk Halperin, Israel B. Lewner, Kadisz Jehuda-Lejb Silman, Simcha Ben-Cijon, Aron Luboszycki.

${ }^{49}$ Ukazywały się jako oddzielne, kilkustronicowe publikacje, zebrane później w dwa tomy. Niektóre tytuły pokrywały się z publikacjami z serii Perachim.

${ }^{50}$ Były to przede wszystkim biografie filozofów i postaci historycznych. Ze'ew Gries omawia wybranych autorów książeczek, a zwłaszcza tych, którzy kontynuowali pracę pedagogiczno-literacką po emigracji do Palestyny. Gries, The Revolution..., s. 186-189. 
Serie wydawnicze „Tusziji” stanowiły potężny wkład do rozwoju literatury dziecięcej jako nieodłącznej części literatury hebrajskiej ${ }^{51}$. Ponadto w 1901 r. Ben-Awigdor wraz ze Szmuelem L. Gordonem wydali wspólnie tygodnik skierowany do młodych czytelników. „Olam Katan” [Mały Świat] niósł powiew świeżości, jego szata graficzna i treści odpowiadały duchowi nowego, $\mathrm{XX}$ w. ${ }^{52}$ Periodyk, jak pisał Lewinson, dzięki wyśmienitej redakcji oraz wysokiej sprzedaży, przyćmił swym polotem inne tygodniki dla dzieci, które w następnych dekadach wyprodukowała diaspora hebrajska ${ }^{53}$.

„Gdyby nie Ben-Awigdor, nie byłoby hebrajskiej literatury dziecięcej i młodzieżowej”, pisał z afirmacją Reuwen Brajnin ${ }^{54}$. „Gdyby nie Ben-Awigdor, nie zostałyby odkryte największe młode talenty [literackie]. Gdyby nie Ben-Awigdor, nasze życie kulturalne wyglądałoby zupełnie inaczej" 55 . Słowa Brajnina odnieść można także do projektu, jakim był „Olam Katan” - również w nim odzwierciedlała się dbałość nie tylko o czytelnika, ale też o autora. Oprócz pisarzy z długą praktyką, jak Sztajnberg, Lewner czy Luboszycki, Ben-Awigdor zapraszał do współpracy także twórców zaczynających karierę w dziedzinie literatury dziecięcej. W „Olam Katan” ukazywały się wierszyki Ja’akowa Kahana, Ja'akowa Fichmana, a także nastoletnich wtedy - Zalmana Szneora i Icchaka Kacenelsona ${ }^{56}$.

\section{Szlomo Sreberk - wydawca pragmatyczny}

Wydawnicze nieumiarkowanie Ben-Awigdora przyniosło mu sławę, lecz jednocześnie straty materialne. Różną od zamysłu Ben-Awigdora, bo zdecydowanie bardziej powściągliwą i selektywną politykę wydawniczą prezentował Szlomo Sreberk.

51 Ówczesną recepcję biblioteczek omawia Ofek. Pisarz i redaktor, Jehoszua Chone Rawnicki, który także zajmował się literaturą dla najmłodszych, krytykował m.in. adaptacje dzieł literatury światowej wydawane w „Tusziji”, twierdząc, że w okrojonej wersji odbierały polot oryginałom. Ofek, Sifrut ha-jeladim..., s. 234-238.

${ }^{52}$ Więcej o periodyku zob. tamże, s. 359-363.

${ }^{53}$ Lewinson, Ha-tenua ..., s. 201. Ben-Awigdor z Gordonem postanowili wydać też czasopismo dla starszych dzieci. „Ha-Neurim” nie odniósł jednak sukcesu jak „Olam Katan” - wydawany był tylko przez rok (1904-1905). Z troski o przechodzącą modernizację edukację żydowską wydawcy stworzyli też organ dla nauczycieli - czasopismo „Ha-Pedagog” (1903-1904).

${ }^{54}$ Cyt. za: Jakubowicz, Asot wa-hafec..., s. 65.

55 Tamże.

${ }^{56}$ Ofek, Sifrut ha-jeladim..., s. 361. 
Sreberk, który od piętnastego roku życia pracował w magazynie książek w Wilnie, z bliska obserwował zabiegi pisarzy usiłujących wydać, a następnie sprzedać swoje książki ${ }^{57}$. Sytuacja ta - w odbiorze Sreberka - uwłaczała ich godności. Pragnienie przywrócenia pisarzom honoru miało być głównym bodźcem do powołania własnego wydawnictwa ${ }^{58}$. Za tą szlachetną ideą podążało jednak myślenie praktyczne: Sreberk uważał, że sprzedaż książek powinna się odbywać według reguł nowoczesnego handlu - jako dochodowe przedsięwzięcie zapewniające zysk zarówno pisarzowi, jak i wydawcy ${ }^{59}$.

Kierując się więc względami ekonomicznymi, Sreberk, przyjął politykę publikacji pożądanych na rynku książek. Ich docelowym odbiorcą miał być przeciętny Żyd. Jednym z głównych założeń wydawcy było publikowanie książek w obu językach żydowskich. Sreberk nie zamierzał ryzykować - w dziedzinie wydawnictwa hebrajskiego nastawiony był przede wszystkim na publikację podręczników, książek do nauki języka czy słowników. Wychodził z założenia, że zanim zacznie się wydawać hebrajską literaturę piękną, należy przysposobić do niej czytelnika żydowskiego, tzn. dać mu narzędzia do opanowania języka. Inaczej w przypadku bardziej popularnej i bliskiej sercu Sreberka literatury jidysz, która nie nastręczała czytelnikom trudności językowych ${ }^{60}$.

Swoją wydawniczą karierę rozpoczął Sreberk od wydawania literatury biblijnej ${ }^{61}$ - słowników biblijnych (Miszpat ha-urim Jehoszuy Sztajnberga), przekładów Biblii na język rosyjski, komentarzy biblijnych autorstwa pisarzy hebrajskich (Mikra meforasz, red. Josef Eliahu Triwosz, Dawid Notik, Natan Lewin) - publikacji, które przez lata cieszyły się dużą popularnością ${ }^{62}$.

${ }^{57}$ Szlomo Sreberk (1876-1944) urodził się w miasteczku Postawy w okolicy Wilna, przyjął tradycyjne wychowanie żydowskie. W 1891 r. przeniósł się do Wilna, gdzie zaczął pracę jako sprzedawca książek. W 1900 r. założył wydawnictwo „Sz. Sreberk”. Po emigracji do Palestyny (1933) kontynuował działalność wydawniczą (założył wydawnictwo „Jizrael”).

${ }^{58}$ Szimon Ernst, Szlomo Zanwil Sreberk, [w:] Szlomo Sreberk, Zichronot ha-moci la-or Szlomo Sreberk, red. Awraham Arje Akawia (Jakubowicz), Tel Awiw 1955, s. 26-27.

59 Tamże, s. 30.

${ }^{60}$ Tamże, s. 28. W wydawnictwie Sreberka ukazały się prace Ba'al Machszawot, Szmuela Nigera, Lipmana Lewina, Falka Halperina czy Icchaka Meira Wajsenberga. Jakubowicz, Asot wa-hafec..., s. 55-57.

${ }^{61}$ Niewykluczone, że przyczyną tego był fakt, iż Wilno było centrum wydawniczym ksiąg świętych judaizmu. W drukarni wdowy i braci Romm publikowano szeroko rozpowszechnianą edycję Talmudu babilońskiego oraz modlitewniki. O drukarni rodziny Romm zob. Ze'ev Gries, Romm Family, [w:] The YIVO Encyclopedia of Jews in Eastern Europe, red. Gershon Hundert, http://www.yivoencyclopedia.org/article.aspx/Romm_Family [dostęp: 29 kwietnia 2016].

${ }^{62}$ Pograbinski, Le-toldot..., s. 50-51. 
Ufundowane w $1900 \mathrm{r}$. wydawnictwo prosperowało dobrze - tylko w 1908 r. wydano ponad sto książek ${ }^{63}$. Jednak pozycję oficyny osłabiły problemy z cenzurą rosyjską, a szczególnie proces sądowy wytoczony Sreberkowi w następstwie publikacji artykułu autorstwa Ba'al Machszawot (jid. Bal Machszowes - pseudonim Izydora Izraela Eliaszewa) ${ }^{64}$. W 1910 r. Sreberk podjął się innego ważnego przedsięwzięcia. Oburzony odkryciem, że wydawcy w Ameryce swobodnie drukują dzieła jednego z największych pisarzy żydowskich - Szaloma J. Abramowicza, znanego jako Mendele Mocher Sfarim (jid. Mojcher Sforim) - bez konsultacji czy wypłacania mu honorarium za dodruki, Sreberk wykupił prawo wyłączności do publikacji pism tego autora ${ }^{65}$. Ukazały się one w specjalnie powołanym wydawnictwie „Mendele”, które stworzył wraz z Ja’akowem Lidskim, właścicielem warszawskiego wydawnictwa „Progres” ${ }^{\prime 6}$. Był to krok wydawcy-mecenasa: wedle własnego gustu i przekonań Sreberk wybrał pisarza, którego pragnął nie tylko wesprzeć, lecz - co więcej - któremu chciał wynagrodzić szkody wyrządzone przez wydawców dowolnie drukujących jego prace ${ }^{67}$. Wprawdzie ruch Sreberka wyglądał na wspaniałomyślny ukłon w stronę wielkiego pisarza, jednak zauważmy, że powieści Mendelego wówczas już należały do kanonu literatury żydowskiej, były przeto obowiązkową lekturą żydowskiego czytelnika. Dawało to Sreberkowi gwarancję sprzedaży książek.

\section{„Central”, czyli wydawcy w komitywie}

Interesy wydawnicze, a przede wszystkim współpraca z Lidskim, przywiodły Sreberka do Warszawy. Spotkał się tam z innymi czołowymi wydawcami - Ben-Awigdorem, Benjaminem Szyminem i Mordechajem Kaplanem. Podjęto decyzję o połączeniu wydawnictw. W skład kooperatywy wydawniczej „Central/Merkaz” [Centrum] weszły hebrajskie i jidyszowe oficyny

${ }^{63}$ Jakubowicz, Asot wa-hafec..., s. 57.

${ }^{64}$ Ernst, Szlomo Zanwil Sreberk..., s. 28-29.

65 „Wierny głównej idei swej działalności, czyli niesienia pomocy pisarzom, [Sreberk] uratował Mendelego z rąk rabusiów, a nawet zadośćuczynił mu, wykupując prawa do publikacji jego dzieł za kwotę, jakiej nie wypłacono dotychczas żadnemu pisarzowi ani żydowskiemu, ani hebrajskiemu". Tamże, s. 31.

${ }^{66}$ Założone w Warszawie w 1910 r., uważane było za pierwsze wydawnictwo nowoczesnej literatury jidysz. Nathan Cohen, Distributing Knowledge: Warsaw as a Center of Jewish Publishing, 1850-1914, [w:] Warsaw: The Jewish Metropolis, red. Glenn Dynner, François Guesnet, Leiden 2015, s. 198. Pisma Mendelego (Ale werk fun Mendele Mojcher Sforim) ukazały się w siedemnastu tomach w latach 1913-1914.

67 Jakubowicz, Asot wa-hafec..., s. 58-60. 
wydawnicze: „Tuszija” Ben-Awigdora, wileńskie wydawnictwo Sreberka, „Progres” Ja’akowa Lidskiego (który już w 1910 r. połączył się z „Ha-Szachar" Mordechaja Kaplana) oraz wydawnictwo Benjamina Szymina „Grojse welt-bibliotek" ${ }^{\prime}$.

„Central” (1911) powstał bez programu czy manifestu, z czego można wnioskować, iż połączenie wydawnictw było rozwiązaniem strategicznym, potrzebą chwili ${ }^{69}$. Wszystko wskazuje na to, że wydawcy kierowali się przede wszystkim względami ekonomicznymi. W 1911 r. pogorszyła się sytuacja finansowa „Tusziji”, działalność wydawniczą Sreberka zawieszano ze względu na niedostosowywanie się wydawcy do zakazów cenzury, a Lidski z Kaplanem połączyli swoje wydawnictwa już wcześniej, najprawdopodobniej z przyczyn rynkowych.

Jednak stworzenie dwujęzycznego wydawnictwa miało też swój wymiar ideologiczny. W kontekście sporów dotyczących wyboru jednego języka narodowego inicjatywa ta wykraczała poza podziały między jidyszystami i hebraistami ${ }^{70}$. Praktyka jednak wzięła górę nad ideologią. Niewielu autorów żydowskich przecież - mimo zagorzałych deklaracji - tworzyło w jednym języku. Założyciele domu wydawniczego „Central” zdecydowali się więc także nie opowiadać za jednym z języków żydowskich, ale publikować ich dwujęzyczną twórczość w całości. To kompleksowe podejście było świetnym rozwiązaniem praktycznym, umożliwiającym publikację na dużą skalę.

Choć Sreberk zajął się sprawami organizacyjnymi ${ }^{71}$, decydujący głos w kwestii linii wydawniczej kooperatywy należał do Ben-Awigdora ${ }^{72}$. Ten jednak, świadom sytuacji rynkowej, wiedział doskonale, także z własnego doświadczenia, że wydawnictwo musi kierować się względami pragmatycznymi, gdyż publikacja literatury pięknej nie zapewni mu bytu. To

${ }^{68}$ Dzieje kooperatywy wraz z informacjami na temat poszczególnych wydawców zob.: tamże, s. 55-92.

${ }^{69}$ Tamże, s. 102.

${ }^{70}$ Przypomnijmy, że „Central” uformowano w kilka lat po słynnej konferencji w Czerniowcach (1908), podczas której odbyła się burzliwa polemika na temat „właściwego języka narodowego" Żydów. Dyskusje nad statusem jidysz oraz hebrajskiego toczyły się od końca XIX w. przez pierwsze dekady XX w. Tak zwana wojna języków przeniosła się nawet do jiszuwu. O konferencji w Czerniowcach zob. Joshua A. Fishman, Czernowitz Conference, [w:] The YIVO Encyclopedia..., http://www.yivoencyclopedia.org/article.aspx/Czernowitz_Conference [dostęp: 3 maja 2016]; o starciach między jidyszystami i hebraistami w Palestynie zob. Aleksandra Geller, O wojnie językowej w Palestynie - wprowadzenie do lektury, „Cwiszn” 4 (2011), s. 86-89.

${ }^{71}$ Według Ernsta połączenie wydawnictw było pomysłem Sreberka, który następnie zajął się nie tylko podstawowymi kwestiami organizacyjnymi, ale był też spiritus movens spółki. Ernst, Szlomo Zanwil Sreberk..., s. 29-30.

72 „Tuszija” była największym składowym wydawnictwem kooperatywy „Central”. 
właśnie kolejna po Bibliotece Hebrajskiej seria wydawnicza Ha-Biblioteka Ha-Gedola [Wielka Biblioteka] przyniosła Ben-Awigdorowi największe straty ${ }^{73}$. Jej rozmach był imponujący: $\mathrm{z}$ bez mała tygodniową częstotliwością publikowano kolejne tytuły - od klasyki literatury rabinicznej w nowych edycjach po dzieła twórców i teoretyków literatury nowohebrajskiej, jak Micha J. Berdyczewski, Jeszajahu Berszadski, Mordechaj Dawid Brandstaetter, Josef Klausner czy Ja'akow Fichman. Pograbinski pisze:

Wprawdzie wydawnictwo [Tuszija] wzbogaciło się poprzez publikację podręczników i słowników, wydanie tych ważnych przecież książek [dzieł literatury hebrajskiej] przynosiło straty i tak urwał się druk Wielkiej Biblioteki w połowie, po prostu $\mathrm{z}$ braku sił i środków ${ }^{74}$.

„Central” miał więc łączyć różne polityki wydawnicze, a także być próbą znalezienia kompromisu. Planowano wydawać wszystkie rodzaje literatury - beletrystykę, opracowania naukowe, materiały pedagogiczne, jak również literaturę popularną oraz prasę ${ }^{75}$. Spółka, prócz założeń ideowo-literackich, wyznaczyła sobie cele praktyczno-ekonomiczne. Jednym z nich było podbicie rynku książkowego w Europie, choć w rzeczywistości największą nadzieję pokładano w odbiorcach z Ameryki ${ }^{76}$. Połączenie wydawnictw pod wspólnym kierownictwem umożliwiało oszczędności na wydatkach administracyjnych ${ }^{77}$. Wszystkie siły miały być skoncentrowane na wydawaniu książek.

Kooperatywa zaczęła swoją działalność z impetem, który trwał do wybuchu wojny. Powoływano oddziały wydawnictwa, m.in. w Nowym Jorku

${ }^{73}$ Straty te zaś spowodowały, jak sugeruje Jakubowicz, że wydawnictwo nie było w stanie utrzymać się jako niezależne. Jakubowicz, Asot wa-hafec..., s. 79.

${ }^{74} \mathrm{~W}$ serii ukazało się ok. 80 książek. Pograbinski, Le-toldot..., s. 46. Podobną refleksję miał Fichman, który wskazywał na utopijność ekspansywnych planów wydawniczych Wielkiej Biblioteki. „Największym defektem [Wielkiej Biblioteki] był brak linii” pisał poeta. „Szmuel Ha-Nagid nie czuł się dobrze w towarzystwie Icchaka Kacenelsona, Szmuela Nigera czy Ja'akowa Fichmana. Czytelnicy nie zrozumieli zamiarów Ben-Awigdora i byli wobec nich zdystansowani. Ben-Awigdor natomiast nie rozumiał, że rozwój nie polega tylko na poszerzaniu, ale również na potrzebie zawężenia”. Ja'akow Fichman, Chamisza molim, [w:] Ha-Sefer Ha-Iwri 1914-1924, Warsza 1924, s. 15.

75 W dziedzinie literatury hebrajskiej „Central” zamierzał realizować politykę wydawniczą „Tusziji”, na polu literatury jidysz natomiast miał kierować się założeniami wydawnictwa Szymina. Ideologie wydawnicze Ben-Awigdora i Szymina miały de facto wiele wspólnego. Obaj wydawcy wychodzili z założenia, że liczba publikacji wpłynie na efekt jakości. Oba wydawnictwa wspierały literaturę nowoczesną i młodych twórców. Nie były też elitarne i nie miały określonego, „wybranego” grona odbiorców. Jakubowicz, Asot wa-hafec..., s. 165.

76 Tamże, s. 132.

77 Pograbinski, Le-toldot..., s. 46. 
i Wilnie, wykupowano gazety oraz nawiązywano liczne kontakty (także $\mathrm{z}$ innymi wydawnictwami) w celach dystrybucyjnych ${ }^{78}$. Przy „Central” powołano nawet pomniejsze wydawnictwa - „Achi’sefer” i „Literatur”.

W pierwszych latach istnienia „Central” nie przewidywano publikacji nowych książek, ale planowano edycję tytułów wydawanych dotychczas przez oficyny składowe $\mathrm{z}$ tą różnicą, że teraz ukazywać się miały pod wspólną nazwą. Książki hebrajskie miały być wydawane w specjalnie na ten cel powołanym oddziale kooperatywy - „Achi'sefer" ${ }^{\prime \prime}$. W pierwszym okresie działalności „Central”, czyli do wybuchu I wojny światowej, w serii wydawniczej „Achi'sefer” zatytułowanej Biblioteka Kelalit [Biblioteka Ogólna] ukazało się 18 książek (w rzeczywistości 8 tytułów) - wszystkie pod redakcją Dawida Friszmana ${ }^{80}$. Jak wskazywała nazwa biblioteki, seria nie miała sprecyzowanej linii, a ogłaszane w niej publikacje były dość różnorodne. Obejmowała oryginalne dzieła literatury hebrajskiej autorów bardziej znanych (Dawid Friszman, Icchak Kacenelson) bądź mniej znanych (Cwi Zwulun Wajnberg), tom dzieł krytycznych Menachema Mendla Fajtelsona oraz przekłady z literatury światowej (Jakoba Wassermanna, Augusta Strindberga, Hansa Ch. Andersena). Prócz serii Biblioteka Ogólna oficyna „Achi'sefer” wydała książki Michy J. Berdyczewskiego oraz Szaula Israela Hurwica, a także zbiór literacki „Netiwot” [Ścieżki] (1913, red. Fiszel Lachower).

Podobnie jak w przypadku „Tusziji” ważną, a przy tym najbardziej zyskowną częścią produkcji wydawniczej „Central” była literatura przeznaczona dla dzieci i młodzieży. W 1913 r. powtórnie wydano biblioteczki „Tusziji” - Perachim i Bikurim ${ }^{81}$. Nową inicjatywą w sekcji dziecięcej była biblioteczka Mikra - owoc współpracy „Central” z wydawnictwem „Sifrut” Fiszela Lachowera ${ }^{82}$. Oprócz opowieści biblijnych seria prezentowała teksty

${ }^{78}$ W 1914 r. na przykład kooperatywa wykupiła gazetę żydowską „Dos Leben” (wcześniejszy tytuł: „Der Frajnd”). Jakubowicz, Asot wa-hafec ..., s. 129.

79 Tamże, s. 167.

${ }^{80}$ Pograbinski, Le-toldot..., s. 47.

${ }^{81}$ W „Central” ukazały się także wznowione edycje Ba-ir u-wa-ja'ar [W mieście i w lesie] i Sichot jeladim [Rozmówki dziecięce] Jehudy Sztajnberga oraz Kol agadot Israel [Wszystkie legendy żydowskie] Israela B. Lewnera.

82 Wydawnictwo „Sifrut” [Literatura] miało założenia idealistyczne - drukować literaturę piękną i wspierać młodych autorów. Wschodzący krytyk literacki, Fiszel Lachower, powołał je własnym sumptem i osobiście nim kierował. Rezultaty były godne podziwu w myśl wstępnych założeń wydawał jedną książkę miesięcznie. W wydawnictwie ukazały się dziesiątki publikacji utalentowanych pisarzy, jak: Icchak Kacenelson, Dawid Szymoniwicz, Jehuda Sztajnberg, Hillel Cejtlin, Josef Chaim Brenner, Aron Awraham Kabak czy Zalman Szneor. Lachower zaczął wydawać także wspomnianą biblioteczkę dla dzieci - Mikra, 
znanych twórców (Icchaka Kacenelsona, Jehudy Sztajnberga, Zalmana Szneora, Dawida Friszmana), mające na celu ułatwić młodym czytelnikom lekturę tekstów hebrajskich ${ }^{83}$.

Właściciele „Central” mieli w planach wydanie specjalistycznych słowników hebrajskich, a nawet nową poprawioną edycję Talmudu babilońskiego z komentarzami ${ }^{84}$. Jednak wybuch Wielkiej Wojny przerwał nie tylko działalność wydawniczą „Central”, ale także większość wymienionych projektów.

\section{Międzywojnie}

Jeżeli przełom wieku XIX i XX postrzega się jako okres świetności hebrajskiego ruchu wydawniczego na ziemiach polskich, a w szczególności w Warszawie, to wybuch I wojny światowej stanowi jego cezurę ${ }^{85}$. Nowa sytuacja geopolityczna w Europie wpłynęła na życie Żydów polskich - nadzieje na równouprawnienie w odnowionej Polsce szybko znikły, pogarszała się sytuacja ekonomiczna oraz polityczna. W konsekwencji tego zwiększała się emigracja do krajów zachodnich, a przede wszystkim do Ameryki i Palestyny. Odpowiednio więc spadała zarówno liczba czytelników, jak i twórców oraz propagatorów literatury w diasporze, w tym redaktorów, wydawców i drukarzy. Wraz z przeniesieniem się prominentnych pisarzy i działaczy politycznych do Ziemi Izraela, translokacja „centrum kulturalnego" Żydów stała się faktem. Gwałtowny rozwój ruchu wydawniczego w Palestynie, datowany na połowę lat dwudziestych, znacząco wpłynął na wydawnictwa w diasporze. Czytelnicy hebrajscy często identyfikowali się z ideologią syjonistyczną, wobec czego żądni byli nowej literatury pisanej w jiszuwie, wieści z tamtejszych gazet czy najnowszych podręczników ${ }^{86}$.

a także dwa periodyki literackie (oba pod redakcją Friszmana): „Sifrut” (1908-1909) i „Reszafim" (1908-1910), które w historii literatury hebrajskiej należą do najlepszych zbiorów literackich z początku XX w. Pograbinski, Le-toldot ..., s. 52-53.

${ }_{83}$ Jakubowicz, Asot wa-hafec ..., s. 177-178.

${ }^{84}$ Pograbinski, Le-toldot, ,,, s. 46-47.

${ }^{85} \mathrm{O}$ Warszawie jako centrum hebrajskiego życia literackiego zob. Avner Holtzman, Warszawa, rok 1900: miejsce narodzin nowoczesnej kultury hebrajskiej, tłum. Olga Danek, [w:] Polskie tematy $i$ konteksty literatury żdowskiej, red. Eugenia Prokop-Janiec, Marek Tuszewicki, Kraków 2014, s. 213-221; Dan Miron, Bodedim be-moadam, Tel Awiw 1987, s. 31-36, 370-379.

${ }^{86}$ Ze sporządzonego przez Urząd Celny w Palestynie raportu z importu i eksportu książek hebrajskich w latach 1923-1935 wynika, że Polska zajmowała pierwsze miejsce wśród państw europejskich importujących książki wydawane w Palestynie. Mosze Beluszer, Kama Erec-Israel kona we-mocheret sefarim, „Dawar” 3531 (23 grudnia 1936), s. 5. Fakt ten nie będzie zaskakujący, jeśli weźmiemy pod uwagę, że w Polsce znajdowała się jedna z najbardziej 
W okresie międzywojennym książki hebrajskie często drukowane były w oficynach żydowskich oraz polsko-żydowskich, praktykowano też powoływanie projektów wydawniczych przy czasopismach ${ }^{87}$, stowarzyszeniach oświatowych (przede wszystkim Tarbut) czy ugrupowaniach syjonistycznych $^{88}$. Ich działalność jednak była zazwyczaj uzależniona od czasu funkcjonowania danych inicjatyw. Nadal też zdarzało się, że pisarze wydawali swą twórczość prywatnie, własnym sumptem ${ }^{89}$. Literaci i popularyzatorzy kultury podejmowali próby powołania w Polsce wydawnictw hebrajskich, lecz zazwyczaj utrzymywały się one zaledwie przez kilka lat, produkując niewielką liczbę publikacji ${ }^{90}$. Wśród nowo powołanych oficyn warto wspomnieć krakowskie wydawnictwo „Miflat” [Przystań] ${ }^{11}$, założone przez członków lokalnego oddziału Zrzeszenia Literatów i Dziennikarzy Hebrajskich (działające w latach 1933/34-1939), oraz „Snunit” [Jaskółka] Naftalego Zigla (Siegla) we Lwowie (publikujące w latach 1919-1936) ${ }^{92}$.

licznych wspólnot żydowskich na świecie. O rynku książkowym w Polsce międzywojennej zob. także Lewinson, Ha-tenua..., s. 210-219; Lewi Gutgald, Al szuk ha-sefer ha-iwri be-Polanja, „Ha-Cefira” 114 (31 lipca 1931), s. 6.

${ }^{87}$ Na przykład przy warszawskich „Kolot” [Głosy] (1923-1924) czy „Reszit” [Początek] (1932-1934), wileńskich „Galim” [Fale] (1929-1930), a także lwowskim „Ha-Solel” [Brukarz] (1932-1934). Wydawano w nich zazwyczaj literaturę piękną bądź naukową autorstwa lokalnych pisarzy.

${ }^{88} \mathrm{Na}$ przykład serie wydawnicze He-Chaluc czy Ha-Szomer Ha-Cair, a także Jesodot i $\mathrm{La}-\mathrm{kol}$.

${ }^{89}$ Lewinson, Ha-tenua ..., s. 210.

${ }^{90} \mathrm{~W}$ Warszawie w międzywojniu kontynuowały swą działalność założone jeszcze przed wojną takie wydawnictwa, jak „Ha-Or” pedagoga Magnusa Kryńskiego (przede wszystkim literatura dla dzieci w jidysz i hebrajskim oraz materiały do nauki języka) czy „Ha-Cefira” z „Ha-Sefer”, jednak wydały drukiem pojedyncze tylko książki. Oprócz nich działały małe wydawnictwa, jak „Traklin” (głównie literatura średniowieczna, filozoficzno-religijna), „Ha-Makor” (prawdopodobnie prywatny projekt Jehudy Warszawiaka - ukazały się w nim wyłącznie jego publikacje: powieści, opowiadania, antologie) czy „Medura”, publikujące tłumaczenia przede wszystkim z literatury rosyjskiej.

${ }^{91}$ Kierowali nim członkowie Zrzeszenia: Cwi Fefer, Bencijon Benszalom (Kac) i Zacharja Zilberpfenig (Kasif). Założyciele wydawnictwa wyznaczyli sobie niełatwy cel: publikację literatury naukowej i oryginalnej twórczości pisarzy hebrajskich z Polski - dużo mniej poczytnych niż tłumaczenia literatury obcej czy przedruki dzieł wydawanych w Palestynie, a także mniej dochodowych niż podręczniki i materiały dydaktyczne. W ciągu kilkuletniego istnienia „Miflat” wydało łącznie pięć publikacji: monografię dzieł Uriego Nisana Gnessina pióra Bencijona Benszaloma (1934), zbiory artykułów filozoficznych Bencijona Rapaporta (1936) i Menachema (Edmunda) Steina (1938), almanach literacki „Sefer ha-Szana Li'Jehudej Polanja” (1937) oraz zbiór poezji Bera Pomeranca (1939). Zacharja Zilberpfenig, Ma'i „Miflat”?, „Sefer Ha-Szana Li’Jehudej Polanja” 1 (1937), s. 354; Zacharja Kasif (Zilberpfenig), Mifalej Tarbut, [w:] Sefer Kroke: ir wa-em be-Israel, red. Arje Bauminger, Meir Bosak, Natan Michael Gelber, Jeruszalajim 1959, s. 342-343.

${ }_{92} \mathrm{~W}$ „Snunit” drukowano przede wszystkim literaturę dla dzieci i młodzieży (biblioteczki Iwrit chaja i Eden) obejmującą materiały edukacyjne - podręczniki, literaturę he- 
Omówione wcześniej wydawnictwa, „Achi'asaf” czy „Central”, reaktywowały swoją działalność. „Achi'asaf” jednak jeszcze przed wojną stracił swój rozmach, głównie za sprawą konkurencyjnego wydawnictwa „Tuszija”93. Wznawiając w 1919 r. działalność, „Central”, jak pisał Jakubowicz, musiał dostosować się do nowych warunków, tj. czytelników preferujących czytanie w jidysz ${ }^{94}$. Z myślą o całkowitym wycofaniu się ze współpracy Ben-Awigdor usunął się w cień, snując plany powołania wydawnictwa w Palestynie. W efekcie na czoło kooperatywy wysunął się Szymin. Jego ostrożna polityka skutkowała ograniczeniem produkcji wydawniczej - w pierwszych latach powojennych „Central” publikował przede wszystkim jidyszowe serie dla dzieci i młodzieży.

Ciosem, który nieoczekiwanie spadł na hebrajski ruch wydawniczy w ogóle, a na hebrajską stronę kooperatywy w szczególności, była nagła śmierć Ben-Awigdora (1921). Jego odejście zmieniło układ sił i linię „Central”. Dział literatury hebrajskiej, za który był odpowiedzialny Ben-Awigdor, został zaniedbany i zmniejszony. Uwaga wydawców przesunęła się w kierunku literatury jidysz. W 1922 r. Sreberk przeniósł się wraz ze swoim wydawnictwem do Warszawy i wysunął na czoło kierownictwa spółką. W ciągu zaledwie dwóch lat od reaktywowania działalności „Central” wydano setki woluminów - część wydań wznowionych, ale także nowych, oryginalnych książek oraz tłumaczeń - od podręczników i czytanek dla uczniów, przez antologie, słowniki, wybory pism klasyków żydowskich, po pocztówki i nuty. Zdecydowana większość publikacji była w języku jidysz.

Mimo że w 1926 r. wznowiono również działalność „Achi’sefer”, także w tej pierwotnie hebrajskiej serii przeważały książki w jidysz - od publikacji historycznych, jak dzieje prasy żydowskiej Szmuela L. Citrona czy historia literatury żydowskiej Noacha Pinesa, po liczne powieści oraz wielotomowe edycje pism zebranych Jakuba Dinezona czy Mordechaja Spektora. Podobnie - dzieła autorów dwujęzycznych, znanych dobrze z twórczości hebrajskiej, w międzywojennym „Achi'sefer” publikowano raczej w jidysz

brajską źródłową oraz oryginalne utwory literackie. Serie te, podobnie jak wydana w latach trzydziestych Biblioteka dla Dorosłych, nastawione były na poszerzanie znajomości języka hebrajskiego czytelników. W „Snunit” ukazywały się także publikacje religijne i filozoficzne - najczęściej autorstwa lokalnych pisarzy (Reuwena Fahna, Cwi Karla czy Abe Apfelbauma) - oraz książki w jidysz. Zasadniczo wydawnictwo nie publikowało hebrajskiej literatury pięknej.

${ }_{93}$ Po wojnie w wydawnictwie ukazały się m.in.: ostatni tom „Luach Achi'asaf” (1923), pisma Theodora Herzla, Jehoszuy Ozjasza Thona oraz Icchaka Grünbauma, a także nowe edycje wcześniej publikowanych książek, przede wszystkim podręczników.

${ }_{94}$ Jakubowicz, Asot wa-hafec..., s. 179. 
(Citron, Friszman). W języku hebrajskim wydawano przede wszystkim podręczniki do nauki języka i inne materiały dydaktyczne ${ }^{95}$, pojedyncze tomy klasyków hebrajskich (pisma Awrahama Mapu czy powieść Pereca Smolenskina ${ }^{96}$ ) i kilka przekładów literatury młodzieżowej (Marka Twaina i Thomasa Reida). Była to prawdopodobnie kontynuacja zachowawczej polityki wydawniczej Sreberka, stosowana wcześniej w jego własnym wydawnictwie. Ponieważ powieści w jidysz miały zapewnionych odbiorców, wydawcy nie chcieli narażać oficyny na straty poprzez druk niepoczytnej literatury hebrajskiej. Preferowanym produktem hebrajskojęzycznym były zatem materiały do nauki wykorzystywane powszechnie w szkołach hebrajskich ${ }^{97}$. Tę praktykę wydawniczą realizował „Central” do końca swej działalności, czyli aliji Sreberka w 1933 r.

W międzyczasie jednak na scenie hebrajskiego ruchu wydawniczego pojawiła się nowa postać, która nie tylko go zrewolucjonizowała, ale pokazała zarówno hebrajskim twórcom, jak i czytelnikom, że literatura hebrajska nadal ma oddanych zwolenników.

\section{Awraham Josef Sztybel - miłośnik literatury hebrajskiej}

Kiedy nastoletni jeszcze Awraham Josef Sztybel ${ }^{98}$ przybył do Warszawy w 1904 r., zetknął się z legendarnymi już wtedy oficynami „Achi'asaf” czy „Tusziją”, wydawcami - jak Ben-Awigdor, a także świetnymi redaktorami - Dawidem Friszmanem i Zeligiem Słonimskim. Wtedy też na dobre rozpoczęła się jego fascynacja działalnością wydawniczą. Początkowo obserwował pisarzy i podglądał pracę redaktorów i wydawców zza

${ }^{95}$ Podręczniki Ja'akowa Fichmana, Icchaka Kacenelsona, Icchaka Berkmana, Chaima Arie Kaplana, Mordechaja Manosa Monosewicza i Szmuela Szewacha Kantorowicza.

${ }^{96}$ Pozycje te ukazały się w serii Wybitni Pisarze Hebrajscy. W dostępnych katalogach figurują jedynie pisma wymienionych autorów (wydane w latach 1928-1929).

${ }_{97}$ Ważnym $\mathrm{i}$ jednym $\mathrm{z}$ największych, a zarazem najdroższych projektów wydawniczych „Achi'sefer” była publikacja monumentalnego dzieła historycznego Heinricha Graetza $\mathrm{Hi}$ storia Żydów (niem. Geschichte der Juden von den ältesten Zeiten bis auf die Gegenwart, jedenaście tomów wydanych w latach 1853-1875) w przekładzie na język hebrajski. Druk pracy ruszył w 1930 r. Do roku 1931 z tygodniową regularnością ukazywały się kolejne zeszyty, zebrane potem w sześciu tomach. Przekładu podjęli się Szmuel Lejb Citron, Awraham Szalom Kamieniecki i Awraham Ben-Ori.

${ }_{98}$ Awraham Josef Sztybel (Stybel), 1885-1946, urodzony w Żarkach, przyjął tradycyjne wychowanie żydowskie. Po studiach w jesziwach, m.in. w Zduńskiej Woli, przygotowywał się do egzaminów rabinackich. Jednak jego zainteresowania literaturą, a także rachunkowością spowodowały, że zarzucił myśl o rabinacie. 
witryn ich oficyn, lecz wraz z powiększaniem swego majątku' ${ }^{99}$ zaczą się osobiście angażować w dystrybucję i promocję literatury hebrajskiej oraz jej finansowe wsparcie ${ }^{100}$, by dekadę później stać się kluczową postacią hebrajskiego ruchu wydawniczego na świecie ${ }^{101}$.

Kiedy po wybuchu rewolucji w Rosji Sztybel przeniósł swe nowo założone wydawnictwo z Moskwy do Warszawy, w symboliczny sposób przywrócił jej dawną świetność ${ }^{102}$. „W naszej literaturze był tylko jeszcze jeden wydawca, który rozmachem dorównał Ben-Awigdorowi”, pisał o Sztyblu Dan Miron ${ }^{103}$. I rzeczywiście, ekspansywność polityki wydawniczej „Hoca'at Sztibel” [Wydawnictwo Sztybla] można porównać z maksymalizmem właściciela „Tusziji”. O ile jednak Ben-Awigdor miał stworzyć literaturę hebrajską i wychować sobie czytelnika, o tyle Sztybel chciał przede wszystkim wzbogacać literaturę hebrajską ${ }^{104}$. Pragnął drukować nową, aktualną twórczość oraz zaopatrzyć bibliotekę hebrajską w dzieła literatury światowej, które miałyby z jednej strony działać inspirująco

${ }^{99}$ Sztybel zajmował się handlem skórami. W czasie I wojny światowej stał się wyłącznym importerem amerykańskich wyrobów skórzanych dla Rosji. Dzięki posiadaniu monopolu był głównym dostawcą skór na buty żołnierzy armii rosyjskiej. Znaczną część majątku, do którego w ten sposób doszedł, postanowił przeznaczyć na realizację swego największego marzenia, czyli wsparcia rozwoju literatury hebrajskiej.

${ }_{100}$ Przede wszystkim periodyki literackie. Sztybel pomagał w znalezieniu subskrybentów dla „Ha-Meorer” (Londyn 1906-1907) Brennera, wstawiał się nawet u rosyjskiego cenzora w celu zdobycia pozwolenia na dystrybucję pisma. Finansowo wsparł także czasopisma „Ha-Iwri He-Chadasz” (Warszawa 1912) Ja'akowa Kahana, „Netiwot” (Warszawa 1913) Fiszela Lachowera czy „Gewulot” (Wiedeń 1918-1920) Gerszona Szofmana.

101 Życie i działalność wydawnicza Sztybla zostały szczegółowo opisane w jego biografii. Zob. Dania Amichaj-Michlin, Ahawat ISZ: Awraham Josef Sztibel, Jeruszalajim 2000; zob. także: Ryszard Löw, Sztybel, „Teksty Drugie” 5 (2001), s. 146-150; Magda Sara Szwabowicz, Abraham Josef Sztybel, [w:] Polski Słownik Biograficzny, t. 49/1, z. 200: „Szpilowski Hilary Szubert Wacław", red. Andrzej Romanowski, Warszawa 2013, s. 143-144.

102 „Hoca'at Sztibel” [Wydawnictwo Sztybla] założono w 1917 r. w Moskwie, pierwszym kierownikiem literackim został Dawid Friszman. W 1919 r. zostało przeniesione do Warszawy, w 1927 r. do Berlina, w 1930 r. do Tel Awiwu. Warszawski oddział reaktywowano na krótko w 1937 r., jednak po wybuchu wojny centrala wydawnictwa ostatecznie przeniosła się do Nowego Jorku (od 1919 r. wydawnictwo posiadało tam swój oddział). Oficyna funkcjonowała jeszcze trzy lata po śmierci Sztybla - do 1949 r. Przygotowania do założenia wydawnictwa oraz pierwsze dziesięciolecie jego działalności opisuje szczegółowo Ben-Cijon Kac, który był stałym doradcą Sztybla w okresie przygotowań do stworzenia oficyny. Ben-Cijon Kac, Ka'awor tekufa, „Ha-Cefira” (28 stycznia 1927; 11 lutego 1927; 18 lutego 1927; 25 lutego 1927; 4 marca 1927; 11 marca 1927).

${ }_{103}$ Miron, Bodedim ..., s. 33.

104 Plany wydawnicze Sztybla, w przeciwieństwie do zamysłów Ben-Awigdora czy Sreberka, nie obejmowały publikacji podręczników i materiałów dydaktycznych. Mimo to oddział telawiwski pod nadzorem Nachuma Twerskiego wydał kilka podręczników i skryptów z czytankami dla uczniów. 
na twórców hebrajskich, z drugiej zaś umożliwiać zapoznanie czytelnika hebrajskiego z klasyką ${ }^{105}$.

„Hoca'at Sztibel” była wydawnictwem o szerokim zasięgu, nastawionym na dystrybucję ogólnoświatową, z oddziałami w kilku krajach, przede wszystkim w Nowym Jorku i Tel Awiwie. Pierwsza dekada ponadtrzydziestoletniej działalności wydawnictwa zapisała się jako najbardziej pomyślna ${ }^{106}$. W oficynie Sztybla opublikowano ogółem ponad pięćset tytułów hebrajskiej literatury pięknej i naukowej oraz ponad sto przekładów literatury obcej, w tym kilkanaście dzieł literatury polskiej ${ }^{107}$. Prócz tego Sztybel - pomny doskonałych czasopism literackich, zwłaszcza tych redagowanych przez Friszmana - pragnął przywrócić świetność prasy hebrajskiej. Jego wydawnictwo podjęło inicjatywę wydania dwóch periodyków - „Ha-Tekufa” [Epoka] i „Miklat” [Schronienie] ${ }^{108}$. „Ha-Tekufa” stała się najważniejszym hebrajskim zbiorem literackim w międzywojennej diasporze ${ }^{109}$.

105 Sztybel niechętnie też odnosił się do wydawania pism zebranych. Mimo że w wydawnictwie ukazały się dzieła zebrane Michy J. Berdyczewskiego, Josefa Ch. Brennera czy Gerszona Szofmana, to kiedy w połowie lat trzydziestych Ja'akow Kahan zwracał się doń z prośbą o wydanie swojej twórczości, Sztybel konsekwentnie mu odmawiał: „Wydania wielotomowe nigdy nie były bliskie memu sercu. Od zawsze moim pragnieniem było poszerzanie i wzbogacanie literatury poprzez rozwój twórczości oryginalnej oraz wprowadzanie klasyki literatury obcej”. Wydawca twierdził nawet, że to właśnie druk dzieł zebranych Berdyczewskiego (w dwudziestu tomach) uśmiercił jego wydawnictwo. Cyt. za Amichaj-Michlin, Ahawat ISZ ..., s. 345.

${ }^{106} \mathrm{~W}$ większości tego okresu wydawnictwo ulokowane było w Warszawie.

${ }^{107} \mathrm{Z}$ literatury polskiej w wydawnictwie Sztybla ukazały się: Ogniem i mieczem (Ba-esz u-wa-cherew) Henryka Sienkiewicza (tłum. Azri'el (Edward) Natan Frenk, Warszawa 1919-1921); Irydion (Iridion) Zygmunta Krasińskiego (thum. Chaim Szalom Ben-Awram (Abramson), Warszawa 1920); Pan Tadeusz (Pan Tadeusz) Adama Mickiewicza (thum. Josef Lichtenbaum, Warszawa 1921); Koniec Mesjasza (Szabtaj Cwi) Jerzego Żuławskiego (thum. Mosze Blajsztift, Warszawa 1924); Chłopi (Ikarim) Władysława S. Reymonta (tłum. Chaim Sz. Ben-Awram, Tel Awiw 1928); Anhelli (Anheli) Juliusza Słowackiego (thum. M. Seter (Daniel Leibel), Tel Awiw 1929); Quo Vadis (Kwo Wadis) (thum. Chaim Sz. Ben-Awram, Tel Awiw 1929) i Potop (Ha-Mabul) Henryka Sienkiewicza (ttum. Azri'el N. Frenk, Awraham Lewinson, Tel Awiw 1930; Berlin-Tel Awiw 1931); Król Maciuś Pierwszy (Ha-melech Matja ha-riszon) Janusza Korczaka (tłum. Josef Lichtenbaum, Tel Awiw 1933); Zemsta rodu Kabunauri (Nekamato szel ha-kabunauri) Heleny Bobińskiej (tłum. Josef Lichtenbaum, Tel Awiw 1935); Wesele (Ha-chatuna) Stanisława Wyspiańskiego (tłum. Ber Pomeranc, Warszawa 1938). Przekłady poezji polskiej (Mickiewicza, Słowackiego, Konopnickiej) ukazywały się także w kwartalniku „Ha-Tekufa”. O losach niektórych spośród tłumaczonych dzieł (Sienkiewicza, Wyspiańskiego) pisał szczegółowo Ryszard Löw. Por. Ryszard Löw, Znaki obecności. O polsko-hebrajskich i polsko-żydowskich zwiazkach literackich, Kraków 1995; tenże, Rozpoznania. Szkice literackie, Kraków 1998.

${ }^{108}$ Miesięcznik „Miklat” pod redakcją Icchaka Dowa Berkowica ukazywał się w nowojorskim oddziale pisma w latach 1919-1921.

109 Ten monumentalny kwartalnik, zgodnie z zapatrywaniami Sztybla, prezentował wybór najwyśmienitszej literatury światowej i hebrajskiej. Ukazywał się z przerwami w latach 
Strategia wydawnicza Sztybla nie miała precedensu w dziejach nowożytnej literatury hebrajskiej. W ujęciu Ben-Eli'ezera Sztybel „stał się mecenasem spieszącym wzbogacić pisarzy i wydawcą spieszącym wzbogacić literaturę"110. Postawa ta wzbudzała szacunek wśród innych wydawców, co uwiecznił w swoich wspomnieniach Sreberk:

Zdaje się, że nie było w naszej literaturze podobnego mu wydawcy. Mieliśmy kilku dobroczyńców, wśród nich warto wspomnieć Kalonimusa Ze'ewa Wysockiego, który wspomógł „Achi’asaf” w wydaniu „Ha-Sziloach”, i Rabbiego Israela Maca, który powołał fundusz na publikację periodyku „Ha-Tora”. Ale nie ma obecnie filantropa i nie ma wydawcy, o którym powstałoby tyle legend, co wokół Awrahama Josefa Sztybla, bo zaprawdę wspaniały był to człowiek, kochał literaturę hebrajską i gotów był się jej prawdziwie poświęcićn ${ }^{111}$.

Sztybla charakteryzowało osobiste podejście do literatury oraz projektu, którego wykonania się podjął. Nie poprzestał na wybraniu na naczelnego redaktora wydawnictwa oraz kwartalnika „Ha-Tekufa” najwyżej przez siebie cenionego pisarza, Dawida Friszmana, sprowadzeniu go z Odessy do Moskwy, wynajęciu mu mieszkania i utrzymywaniu go ${ }^{112}$. Sztybel osobiście zwracał się do autorów, których dzieła chciał opublikować, wyszukiwał odpowiednich tłumaczy i edytorów. Wszystkich ich przyciągał wysokimi zaliczkami oraz honorariami, często płaconymi z góry ${ }^{113}$.

1918-1950. Podobnie jak wydawnictwo redakcja zmieniała miejsce: pierwsze tomy ukazały się w Moskwie, kolejnych dwadzieścia w Warszawie, następnie dwa w Berlinie, a ostatnie w Nowym Jorku.

110 Mosze Ben-Eli’ezer, Szelosza molim, „Giljonot” 15 (1943), nr 6, s. 376. Już sam akt założycielski wyróżniał Sztybla od innych wydawców. Wydawnictwo nie powstało na zasadzie zbiórki funduszy, udziałów kilku wspólników czy spółki. Sztybel założył wydawnictwo $\mathrm{z}$ własnych środków i bynajmniej nie w imię zarobku. Fenomen tej postawy podkreślali współcześni mu pisarze, np. Cwi Zwulun Wajnberg czy Josef Chaim Brenner, wydawcy, jak Szlomo Sreberk, a później także badacze i historycy. Zob. Cwi Zwulun Wajnberg, Adam ba-ohalo, Tel Awiw-Jeruszalajim 1955, s. 195; Josef Chaim Brenner, Mitoch ha-pinkas [A. J. Sztybel], [w:] tenże, Ketawim..., s. 1525-1530; Sreberk, Zichronot..., s. 135-137; Pograbinski, Le-toldot..., s. 37.

${ }^{111}$ Sreberk, Zichronot..., s. 135.

${ }^{112}$ Liczne anegdotki na temat relacji między Sztyblem a Friszmanem przywołuje Amichaj-Michlin. Oprócz wynajęcia czteropokojowego mieszkania i umeblowania go oraz wypłacania Friszmanowi miesięcznej pensji Sztybel dbał także o najdrobniejsze zachcianki redaktora. Zdarzało się, że w czasach kryzysu, kiedy dostępność wybranych produktów spożywczych była ograniczona, Sztybel osobiście stał godzinami w kolejkach, by zdobyć dla Friszmana na przykład... czekoladę. Amichaj-Michlin, Ahawat ISZ ..., s. 41, 46-47.

${ }^{113}$ Kiedy zaś zbankrutował, w roku 1927, wiele z obiecanych honorariów zostało nieuiszczonych. Osobiste podejście Sztybla do projektów wydawniczych miało także swoje słabe strony. Umiłowanie literatury i chęć publikacji nieograniczonej liczby książek stały się w rzeczywistości słabością jego polityki wydawniczej. Sztybel łatwo zapalał się do kolejnych 
Tym samym Sztybel napędzał całą machinę produkcji literackiej poprzez stworzenie godziwych warunków materialnych dla adwokatów, popularyzatorów literatury od pisarzy po redaktorów i tłumaczy, ożywił hebrajskie życie literackie. A ponieważ kierownictwo wydawnictwa przez długi czas (1919-1925, 1937-1939) ulokowane było w Warszawie, można stwierdzić, że Sztybel położył znaczne zasługi dla wskrzeszenia aktywności literackiej pisarzy i publicystów w Polsce. Bezpośredni dostęp do redakcji wydawnictwa umożliwiał pisarzom, np. Eli'ezerowi Sztajnmanowi czy Matitjahu Szohamowi, publikację swych dzieł; mogli też - jak Dawid Friszman, Ja'akow Kahan, Josef Heftman, Josef E. Triwosz, Icchak Kacenelson czy Ber Pomeranc - parać się tłumaczeniem oraz publikować na łamach kwartalnika „Ha-Tekufa”. Nawet po bankructwie Sztybla, rocznym zawieszeniu działalności oficyny, jak również przeniesieniu głównej produkcji wydawniczej do Tel Awiwu kontakty ze Sztyblem i jego zespołem redaktorskim gwarantowały zajęcie twórcom hebrajskim mieszkającym w Polsce.

Sztybla wyróżniała wiara w centrum kultury hebrajskiej w Polsce. Była to postawa niespotykana, gdyż wielu zwolenników ideologii narodowej (zwłaszcza tych osiadłych już w jiszuwie) miało wysoce krytyczny i często negatywny stosunek do inwestowania w rozwój kultury hebrajskiej w diasporze ${ }^{114}$. Dla Sztybla zaniedbanie kultury hebrajskiej w diasporze, a zwłaszcza literatury, było zbrodnią ${ }^{115}$. Kiedy powrócił do Warszawy w połowie lat trzydziestych, działacze i pisarze raczej opuszczali Europę. Sztybel miał w planach nie tylko wznowienie działalności wydawnictwa, ale także publikację czasopisma „Ha-Tekufa” oraz nowego zbioru literackiego - „Zemanim” [Czasy]. Mimo dobrych chęci wydawcy organizacja periodyków przedłużała się, Sztybel podupadał na duchu i zdrowiu. Kiedy późną wiosną 1939 r. wrócił do Warszawy po rekonwalescencji w Ameryce, realizację jego planów wydawniczych ostatecznie przerwał

projektów, werbował pisarzy i obiecywał im hojne wynagrodzenie, choć nie zawsze mógł się z tych obietnic wywiązać. Amichaj-Michlin wspomina też, że Sztybel miał skłonność do dbania o wybranych, swoich ulubionych twórców, kontakty z innymi zaś nierzadko zaniedbywał. Zob. Amichaj-Michlin, Ahawat ISZ..., s. 371-372.

${ }^{114}$ Przypomnijmy, że „szelilat ha-galut” (hebr. negacja diaspory) to pojęcie wpisane w myśl syjonistyczną. O problematyczności relacji między pisarzami z Polski i Ziemi Izraela zob. Natan Cohen, Ha-sewiwa ha-sifrutit ha-iwrit be-Polin (1920-1939) u-kszareja im ha-mimsad ha-sifruti u-necigaw be-Erec-Israel, „Tarbic” 67 (1998), s. 388-395; Magda Sara Szwabowicz, Twórcy i ośrodki literatury hebrajskiej w Polsce międzywojennej, „Studia Judaica" 18 (2015), nr 1, s. 139-143.

${ }^{115}$ Słowa Sztybla z listu do Ja'akowa Kahana. Amichaj-Michlin, Ahawat ISZ..., s. 344. 
wybuch wojny ${ }^{116}$. W 1938 r. zdążyły się jeszcze ukazać w Warszawie cztery publikacje, w tym Wesele Stanisława Wyspiańskiego w przekładzie poety Bera Pomeranca, dramat Matitjahu Szohama oraz historyczna praca Menachema (Edmunda) Steina.

W artykule zostały omówione tylko wybrane inicjatywy edytorskie, związane z postaciami wydawców, którzy odegrali istotną rolę dla rozwoju i modernizacji hebrajskiego świeckiego ruchu wydawniczego. Swoją postawą, służbą na rzecz literatury hebrajskiej, przyczynili się do stworzenia biblioteki hebrajskiej. „Prawdziwy wydawca nie zaspokaja się wydaniem książki, która przynosi natychmiastowy przychód. Nie spocznie, dopóty nie będzie miał w zanadrzu kolejnych planów, nawet jeśli wykraczają poza jego finansowe możliwości"117. Tak postrzegał rolę wydawcy Sreberk, a słowa te można odnieść także do Ben-Awigdora i Sztybla, którzy nieustannie snuli plany dalszych projektów wydawniczych. Poczucie misji, swoistego posłannictwa jako wydawcy - pisał Ben-Eli'ezer - było wspólne dla trzech wielkich wydawców ${ }^{118}$. Ben-Awigdor pragnął dopomóc w tworzeniu pełnowymiarowej biblioteki hebrajskiej, bez ograniczania się do literatury kanonicznej czy ideologicznej. Sreberk dbał przede wszystkim o czytelnika, którego chciał wykształcić do odbioru hebrajskiej lektury poprzez zapewnienie mu niezbędnych narzędzi (podręczniki, słowniki). Sztybel zaś wyznaczył sobie zadanie wzbogacenia księgozbioru hebrajskiego. Setki książek z każdej dziedziny literatury hebrajskiej - beletrystyki, opracowań naukowych, podręczników, literatury dziecięcej-a także ważne periodyki, jak „Olam Katan” i „Ha-Tekufa”, wydane przez Szalkowicza, Sreberka i Sztybla, stanowią nieodłączną część kulturowego dorobku Żydów wschodnioeuropejskiej diaspory oraz literatury nowohebrajskiej w szczególności.

Magda Sara Szwabowicz Zakład Hebraistyki, Uniwersytet Warszawski magda.sara.szwabowicz@gmail.com

116 Sztybel wraz z żoną uciekł z Warszawy w pierwszych dniach wojny. W 1942 r. w Nowym Jorku reaktywował swoje wydawnictwo pod nazwą „Mosad Guslawa we-Awraham Sztibel" (Instytut Guslawy i Abrahama Sztybel), kierownictwo powierzył Icchakowi Zilberszlagowi i Aronowi Cejtlinowi. Trzydziesty, wyczekiwany przez Sztybla tom „Ha-Tekufy” ukazał się dopiero wiosną 1946 r., na pięć miesięcy przed śmiercią wydawcy. Sztybel zmarł nagle 16 września $1946 \mathrm{r}$. w siedzibie wydawnictwa w Nowym Jorku.

117 Cyt. za: Jakubowicz, Asot wa-hafec ..., s. 64.

118 Ben-Eli'ezer, Szelosza molim..., s. 375. 